\title{
Strategies for sustainability in shrinking cities: frames, rationales and goals for a development path change
}

\author{
Ruiying Liu \\ Department of Spatial Planning and Planning Theory, TU Dortmund University, Germany, \\ ruiying.liu@tu-dortmund.de
}

\begin{abstract}
Addressing the challenges and opportunities in shrinking cities requires approaches and strategies different from those that have been applied under growth conditions. Research on shrinking cities has generated a plethora of approaches and strategies for the shrinkage trajectory and has identified sustainability as a guiding principle. However, shrinking city development in practice either cannot confront the situation of shrinkage, or does so without an integrative, consistent approach, while the concept of sustainability has ambiguous meanings, giving rise to competing or contradicting rationales. This paper identifies the need for clearer directions for a reorientation away from the growth-oriented approaches, in conjunction with a critical reflection on what sustainability means for different shrinking cities. Towards this end, it first assembles an overview of the strategic framings behind urban development ideas proffered in the shrinking city discourse, with a focus on the temporal, agential and spatial dimensions and the cross-cutting frame of higher-level interdependencies. Secondly, with a deeper reflection on the inner tensions of the sustainability concept, it distils the key rationales and proposes new strategy-making approaches for a development path change towards sustainable development that responds to different local situations.
\end{abstract}

Keywords: shrinking cities, development strategy, sustainability

www.tsv.fi/tunnus

\section{Introduction}

Urban shrinkage is an increasingly widespread global phenomenon (Martinez-Fernandez et al. 2016; Oswalt \& Rieniets 2006; Turok \& Mykhnenko 2007; Wolff \& Wiechmann 2018). Shrinking cities are driven by more than regional factors such as industrial migration and inter-city competition. They are embedded in 'the great transition' faced by the global society in the 21 st century, including industrial transformation, demographic ageing, and the establishing of a global economic order (Martinez-Fernandez et al. 2016: 35). In addition to these trends reshaping the parameters of urban development, there is also the urgency to achieve global sustainability due to the coming end of fossil-energy-fuelled industrialisation, the crisis of cheap mobility, social polarisation and climate change (Audirac et al. 2010; Oswalt \& Rieniets 2006: 51). As a structural challenge driven by global processes, 
shrinkage is considered an increasingly normal trajectory of urban development rather than a temporary interruption of growth (Cunningham-Sabot et al. 2013; Sousa \& Pinho 2015). It presents challenges for urban sustainability (Fol 2012; Moss 2008; Slach et al. 2019), as well as opportunities for social-ecological sustainability (Dubeaux \& Cunningham-Sabot 2018; D. Haase 2008; Siebel \& Häußermann 1987). The challenges behind urban shrinkage go beyond theories of urban decline and conventional planning limited by a growth-oriented mindset, knowledge and instruments. To effectively address the impacts of shrinkage and to steer development under shrinkage towards sustainability, researchers have called for a new planning 'paradigm', which includes acceptance of shrinkage as a development trajectory, innovative strategies and integrative, consistent approaches (Hospers \& Syssner 2018; Martinez-Fernandez et al. 2016; Müller \& Siedentop 2004; Pallagst \& Wiechmann 2004).

Over the last two decades, the shrinking city discourse has brought to the fore a plethora of innovative approaches and strategies across policy fields and planning levels, with a common focus on re-orienting away from growth impulses and moving towards sustainable development. However, there are challenges to achieving more impact on practice, especially the establishing of integrative, consistent approaches. One of these challenges is conceptual: there is a lack of an integrative perspective to channel that abundance of new ideas into coherent strategic rationales; which is inseparable from the (lack of) consideration of the guiding principle. Sustainability, as this paper will argue, can have different policy implications when considered with different temporal, spatial and social parameters, giving rise to conflicting rationales. Systemic inertia for growth-oriented approaches is another challenge. It has been observed in institutional contexts, development mindset, political culture, technical models of development, lack of tools and expertise (Hall 2009; Kreichauf 2014; Müller \& Siedentop 2004). This challenges the shrinking city discourse to reflect on its coherence, implications and potential as a whole against the existing conditions of urban development.

Thus, this paper assembles an overview of the strategic framings behind development ideas in shrinking city discourse, in order to: firstly, explore the meanings of sustainability as a guiding principle for a re-orientation away from growth; secondly, extract from them clearer directions for a departure from the growth-oriented 'paradigm'; and thirdly, reflect on their coherence with one another and with existing development conditions.

Such an overview needs to take a holistic view of the strategies in the development process in order to take up the perspective of local strategy-making, because the latter must integrate vertical and horizontal, formal and informal, and local and supra-local factors. It should also extend its consideration beyond the shrinkage end of the spectrum and connect to growth conditions. This is because, on one hand, growth and shrinkage can alternate in development trajectories and can be spatially concurrent (Wiechmann 2008a). Thus, the impression of two types of local planning - one for shrinkage and one for growth - with the key strategic choice being a technical matter of switching at the right signals, would not be conducive to strategic thinking. On the other hand, shrinkage should stand alongside growth as a condition to development - which is not necessarily more problematic 
- therefore, planning should develop the competence to achieve progress under either condition (Hirt \& Beauregard 2019; Sousa \& Pinho 2015). The comparability between the two could be key to facilitating a proactive re-orientation in mainstream development discourses towards accepting shrinkage. Therefore, this paper develops a framework to describe local development strategies in multiple dimensions - instead of categories based on the growth or shrinkage orientation - so that it can capture a holistic picture of local strategies and support more detailed comparative studies.

Finally, the local level is the focus of this paper. This does not mean that the consideration of local actions should be limited to the local scale (see Section 4.4). Strategy-making at this level is challenged by the complexity of integrating diverse factors and is situated in the process of reshaping cities - from developing place qualities (Healey 2007) to steering development in a long-term 'path' (Liebmann \& Kuder 2012). 'Path' is of key interest in shrinking city studies because it is a heuristic for understanding what has led cities to their current situation and for strategising how they can become more sustainable.

The structure of this paper is as follows: Section 2 reviews literature on challenges to shrinking cities' planning practices and sustainability as a guiding principle for re-orienting development; Section 3 clarifies the essential dimensions of urban development strategy. Based on these dimensions, Section 4 presents an overview of the strategic frames of sustainable shrinkage in contrast with the growth-oriented ones. Finally, Section 5 further distils the key strategic rationales and strategy-making approaches for a local strategic change, based on a deeper reflection on the inner tensions of the sustainability concept and the diverse development conditions of shrinking cities.

\section{Departure from growth-oriented planning}

Based on the observation of urban shrinkage, researchers have identified the unsustainable consequences and self-reinforcing dynamics of uncontrolled shrinkage processes and argued for policy and planning responses. Because shrinkage as a structural challenge often defies conventional regrowth strategies, without fundamental re-orientation, local responses could be ineffective or could even exacerbate problems. Meanwhile, sustainability - encompassing economic, environmental and social aspects - has emerged as a principle driving a departure from traditional planning.

\section{Lessons from shrinking cities}

Population loss can lead to unsustainable consequences. Firstly, under-utilisation of socio-technical infrastructures resulting from de-population and parallel sprawl development increases public spending and impairs service provision due to higher per capita costs (Hudeček et al. 2019; Moss 2008; Siedentop \& Fina 2010; Slach et al. 2019; Walther 2016). The combination of rising maintenance costs and falling incomes can plunge shrinking cities into a vicious circle of declining liveability. Secondly, the quality of the built environment is threatened as the deteriorating quality of life drives further outmigration and depopulation of the city. Decay of the building stock and public space ensues through disinvestment and abandonment (Bontje 
2004). Maintenance and conversion of the building stock are limited, which means its quality and typology no longer keeps up with consumption patterns and drives groups with higher mobility to relocate elsewhere (Schmidt et al. 2015). In time, demolition could become the fate of derelict buildings or entire neighbourhoods. Thirdly, population loss can have a high social cost. Outmigration as a selective process results in a diminished labour force, unbalanced demography and increase of vulnerable groups (Steinführer et al. 2014; Strohmeier \& Bader 2004). Economic decline and lack of liveability can lead to loss of trust in the government (De Groot 2019; Ročak et al. 2016b). Finally, shrinkage can negatively impact environmental sustainability. The sprawl of urban settlements could continue even during shrinkage as cities compete for residents, leading to lower energy efficiency due to a decentralised spatial pattern and higher per capita dwelling areas, but local governments often lack the knowledge, instruments, means and/or political motivation to deal with this trend (Kroll \& Kabisch 2012; Kübler et al. 2012; Nuissl \& Rink 2005). In regions with already limited population growth, overall sprawl means infrastructure will be over-dimensioned at a regional scale, and new constructions will cause an equal amount of vacancy in other cities (Aalbers \& Bernt 2019; Mäding 2004). Considering the built environment as a resource itself, the sprawl-depopulationdownsizing cycle is a form of collective wasting (Jakle \& Wilson 1992; Jessen 2012).

Planning itself plays a role in the making of shrinkage and its unsustainable outcomes (Cunningham-Sabot et al. 2013; A. Haase et al. 2014). Under a neoliberal ideology that prioritises economic growth over social and environmental concerns, shrinkage associated with economic downturn is not easily accepted by policy-makers, let alone constructively confronted (Pallagst, Fleschurz \& Said 2017; Schatz 2017). The single-minded pursuit of economic development could intensify outmigration (A. Haase et al. 2014) and widen social inequality (Fol 2012), whereas opportunities to make environmental and social progress in ways that growing cities cannot are left unexplored (Knoop 2014; Siebel \& Häußermann 1987). Conventional strategies rely on external private investment as the main resource, and market mechanisms to regulate property development (Hackworth 2014; Rydin 2013); however, in shrinking cities, market mechanisms cannot guarantee essential life services or social justice, nor can they stop the race to the bottom in the housing market (Hackworth 2014; Jessen 2012), prevent unsustainable development patterns on a large scale (Kübler et al. 2012), or address the loss of culture vitality and social cohesion (De Groot 2019). It has been observed that competitiveness-building, a central objective in the pursuit of growth, drives heavy public investment in expansive strategies that could compromise broader goals (Stryjakiewicz et al. 2018), rationalises resource concentration on prime sites at the expense of other areas in need (Berglund 2020), and unreflectingly applies economic models from metropolitan cities to ordinary cities with diverse contexts (Kinossian 2018).

Thus, shrinking city development strategies need to be formulated based on a critical reflection on the dynamics of shrinkage and assumptions underlying traditional planning. Research on planning and policy highlights five main lessons. Firstly, due to the stigmatisation of shrinkage, accepting the prospect of long-term shrinkage is the 
first step in dealing with its impacts (Pallagst, Fleschurz \& Said 2017). Secondly, dealing with the impacts of shrinkage should start with sustaining the quality of life for the remaining population and making adaptations rather than prioritising competition for regrowth and external private investment (Hollander \& Popper 2011; Knoop 2014). This requires both recognising the changing demographic and social profile (Steinführer \& Haase 2007; Strohmeier \& Bader 2004) and re-organising socio-technical infrastructures for the new socio-spatial patterns (Müller \& Siedentop 2004). Thirdly, it is essential to have an approach integrating economic, urban environment and social aspects to achieve sustainable development (Bernt et al. 2012; Bernt et al. 2014). Fourthly, planning should attend to social sustainability while dealing with shrinkage, because strategies of gentrification intensify social inequality (Berglund 2020; Miot 2015) while top-down right-sizing could impair social justice (Audirac 2018; Hollander \& Németh 2011). Finally, planning should make use of the opportunities in shrinking cities for social and ecological sustainability (Dubeaux \& Cunningham-Sabot 2018; D. Haase 2008; Hall 2009; Schilling \& Logan 2008) and place-based economies (Leick \& Lang 2018; Pallagst, Fleschurz \& Said 2017) to create transformative visions in ways that growing cities cannot.

Some of these ideas share the same positions with (strategic) planning theories that are also concerned with sustainable development: planning for changing convictions and envisioning alternative futures (Healey 1997: 244-245); aiming for quality of life, distributive justice, environmental well-being and economic vitality (Healey 2007: 1); addressing structural issues to achieve long-term goals (Friedmann 2004); making integrative strategies and coordinating spatial impacts (Albrechts et al. 2019; Albrechts et al. 2003); inclusivity and co-production (Albrechts 2015; Kunzmann 2013). However, the experience of strategic planning is mostly with large, growing city (regions), and practice often falls short of these ideals. Meanwhile competitiveness-building, growth orientation and market reliance - key issues for shrinking cities - rarely come into question. The more recent transformative theory goes beyond procedural inclusivity, targeting "the structural problems of capitalist society viewed in a global context", asserting that "the problems and challenges that regions, city-regions, and cities are confronted with cannot be tackled and managed adequately either on the basis of the neoconservative perspective or on the basis of the intellectual, technical-legal apparatus and mindset of traditional planning" (Albrechts et al. 2020: 1, 3). Transformative practices are more directly critical of 'the development-as-growth model' (ibid.) and seek alternative development paths preserving 'local self-sustainability' (Hamilton 2003; Magnaghi 2005). This perspective shares much context with the shrinking city discourse, namely the global uneven development and the growth- and market reliance of traditional planning practices.

\section{Sustainability as a guiding principle for shrinking cities}

Neither growth nor shrinkage is the actual goal of planning; they are but the condition for development towards the goal. Here development means qualitative change rather than densification or expansion. The goal of planning is to achieve progress no 
matter which condition it works with (Hirt \& Beauregard 2019; Sousa \& Pinho 2015). Therefore, planning is not about switching between pursuing growth to accepting decline, but making progress guided by values consistent across growth and shrinkage conditions. The question is then: what counts as progress?

Pallagst and Wiechmann (2004) identified sustainable development as a principle driving the departure from conventional regrowth strategies in shrinking cities. This principle considers economic, environmental and social aspects; but operationalised in an era of overall growth, it is nevertheless growth-oriented (e.g. 'smart growth'), which means that the condition of shrinkage would call for a different operationalisation of sustainability principles - such as 'shrinking smart' (ibid.). However, the practice is often focused on physical downsizing, which has implications for social equity (Audirac 2018) and lacks integration with other policy problems (Bernt et al. 2014). The 'Shrink Smart' reports (Bernt et al. 2012; Bernt et al. 2014) stressed the need to comprehensively address economic development, urban regeneration and social cohesion as keys to sustainable development. Herrmann et al. (2016) approached sustainability for shrinking cities with a complex systems perspective on social-ecological systems; but this view generalises shrinking cities into a type of complex system and speaks little of the context of global processes. Finally, views on 'opportunities' for alternative development accentuate the potential for enhancing ecological services, new green spaces, and alternative lifestyles (Dubeaux \& Cunningham-Sabot 2018; D. Haase 2008; Siebel \& Häußermann 1987), which is aligned with considerations for global sustainability.
Exactly what counts as sustainability for shrinking cities is still up for debate. Social inclusion and equity is unquestionably a fundamental value in shrinking city planning (Audirac 2018; Hollander \& Németh 2011), but in the current politico-economic environment, triage measures and gentrification strategies seem inevitable for preserving the self-sustainability of the city (Kreichauf 2014; Rousseau 2009). In terms of economy, the concern for its stability (Herrmann et al. 2016) is overtaken by the debate on what economies there should be, because mainstream economy is often the driver of shrinkage and exclusion (Dax \& Fischer 2018). While some researchers recommend smart restructuring and long-term competitiveness-building (Zakirova 2010), others realise that some deindustrialising cities may simply need to shrink down to a population sustainable by non-industrial economies (Constantinescu 2012). Environmental quality can improve through greening after depopulation, but de-densified settlements have lower resource efficiency with high maintenance costs and energy consumption (Großmann et al. 2013: 224), contrary to planetary sustainability. Even when a city is socially inclusive and has resource-efficient infrastructures, converting a small town population's lifestyle to the consumptive urban lifestyle could still undermine planetary sustainability (Lehtinen 2018).

There is no universal definition of sustainability, even though it is a universally embraced value. It works more as a framing device for strategic reasoning, channelling values and principles into specific contexts to generate strategic rationales; the more specific the situation, the more specific the rationales. However, this means a general theory on strategies for sustainability in 
shrinking cities difficult, because there are different temporal, spatial and social parameters to consider, which also change over time. This leads to different rationales, and these lead to different, even inconsistent approaches and strategies. This conceptual inconsistency side by side with the lack of planning levers, makes a decisive re-orientation with a consistent approach challenging.

Therefore, the following sections will firstly assemble an overview of the framings of urban development from the shrinking city discourse and will use it as basis for a deeper reflection on the multiple facets of sustainability in order to unpack the tensions between different approaches and strategies.

\section{Reconceptualising local development strategy}

This section develops a conceptual framework of local development strategy as an emergent pattern with temporal, spatial and agential dimensions. Its background is a need for comparative studies on shrinking city development strategies: on one hand, on a general, theoretical level, an overview of the approaches and strategies proposed for shrinking cities is needed to examine how they as a whole depart from growth-oriented approaches and strategies, and how coherent or contested they are, instead of taking the impression of a new 'paradigm' for granted. Pallagst, Fleschurz, and Said (2017) proposed a four-phase typology of shrinking cities' strategies - decline as a vicious cycle, expansive strategies, maintenance strategies, and planning for decline. But more comprehensive reflections need to move beyond typologies. Großmann et al. (2013) suggested that urban policies can be classified based on objectives - growth-oriented or shrinkage-accepting/-mitigating policy responses - or based on a spatial focus, on areas of decline or on areas of growth potential. In addition, the capability of strategy-makers to steer development also fundamentally shapes strategies. On the other hand, there is a need for comparative research to understand specific cases of shrinking city development strategies more comprehensively and consistently for comparison, because shrinking city planning practices often employ mixed approaches rather than single orientations (Schatz 2017). This two-fold need requires a framework with differentiated dimensions for strategic reasoning to allow for a more holistic and nuanced description of strategies.

Strategy is a course to achieve the fundamental goals of the acting organisation; and a development strategy is an emergent pattern owing to the social, spatial and temporal complexity of its processes (Wiechmann 2008b). Strategy-making, especially from a descriptive point of view, is not limited to specific institutional arena or procedure, such as spatial strategic planning, because strategies at play in urban processes do not always trace back to this process. In other words, what ends up realised in action is often not what is planned or plannable beforehand (ibid.). A long-term strategy, such as an industrial-commercial path (Liebmann \& Kuder 2012) has different levels of abstraction and is complemented with situated tactics: it starts from the decision to pursue industrial and commercial sectors, but also includes half-planned or unplanned actions of transforming socio-spatial conditions and attracting businesses in response to market trends. Furthermore, in times of crisis, community self-help and co-production 
initiatives outside the usual channel of centralised strategy-making step in to fill the gap in organised responses, often bypassing plan-making; these actions could slowly become normalised practices facilitated by formal institutions (e.g. Haase et al. 2012; Murtagh 2016). Thus, the narrow definition of strategy as a calculated, predesigned plan of action does not describe strategies in urban development. The latter are products of complex processes characterised by contingencies, socio-material interactions, and distributed, reflexive, foresightful agency. It would help to conceptualise a path change by seeing strategy-makers as actors who steer emergent paths through learning, reflecting, continuously integrating and adjusting (Garud \& Karnøe 2003; Hay 1995; Mintzberg 1990; Quinn \& Voyer 1998), cultivating serendipity, constructing opportunity spaces to counteract path dependency (Garud \& Karnøe 2001; Grillitsch \& Sotarauta 2018).

The emergence of development strategies has three essential dimensions:

The temporal dimension. Strategic planning in urban development is focused on long-term issues (Friedmann 2004; Sorkin 1984) and achieving alternative futures (Albrechts 2015). In such large time frames, complex temporal dynamics shape strategies beyond the point of plan-making, and managing these dynamics is key to path development agency (Grillitsch \& Sotarauta 2018). Approaches to manage temporal complexity include examples such as 'perspective incrementalism' (Karl et al. 1993) and 'mindful deviation' (Garud \& Karnøe 2001). In short, strategy-making in the temporal sense seeks to shape impacts of different temporal scales into a path towards fundamental goals. Goals can be orientating concepts rather than only fixed targets (Bryson 1988; Czarniawska \& Gagliardi 2003). Path creation focuses on how a path is observed, reflected upon and incrementally steered. It is not contradictory to transformative goals of a departure from the current path towards alternative futures, but instead of drastic changes, it considers persistent, incremental changes to counter systemic path dependency to achieve alternative futures (Gáspár 2011).

The agential dimension. The shift towards governance in development strategy-making is key to planning for complex urban areas because it harnesses the imagination of social framing and mobilises distributed agency (Healey 2007). This approach leverages the power of communicative rationality, which emerges from multiple actors and creates strategies differently than individual rationality (Albrechts 2004; Alexander 2000). Furthermore, considered along temporal complexity, agency, instead of being predefined, changes with the dynamic socio-material circumstances (Garud \& Karnøe 2003; Garud et al. 2010). New paths can emerge through abilities given by new circumstances, choices to adapt visions, and redefining what counts as power. Such distributed and embedded agency can be fostered by more complex strategic approaches, for example the 'bricolage' model (Garud \& Karnøe 2003) and institutional capacity-building through transitional governance (van Assche et al. 2020). Therefore, strategy-making is also about cultivating and channelling agency to drive urban development.

The spatial dimension. Strategic spatial planning coordinates economic, environmental and social processes in their spatial manifestation to achieve more coherent and efficient spatial development, especially when there is high pressure from competing 
and/or conflicting demands over spatial resources (Albrechts et al. 2003). Because given time, distributed spatial changes could build up transformations of socio-spatial patterns (e.g. patterns of land use, density distribution, and segregation, and structures like centre-periphery, clusters and networks), and these result in the change of dynamism and potential of the city as a whole. Meanwhile, viewed in relation to the agency dimension, space as socio-material settings is not only a passive receiver of impacts, but also presents constraints and bottom-up forces, such as infrastructure legacies and their governance arrangements, socio-spatial profiles shaped by previous economies as well as endogenous natural and cultural resources waiting to be re-discovered (Liebmann \& Kuder 2012; van Assche et al. 2020). Strategy-making on the spatial dimension is about negotiating changes between top-down and bottom-up forces and shaping their accumulated effects on the territory.

The three dimensions are inextricably intertwined in development strategies. Path dependency is rooted in the socio-material legacies found in the territory (Liebmann \&
Kuder 2012). Path creation is constrained by the community's sense-making of the past, the present and the future, knowledge, imagination, capabilities and resources, and distributed across diverse groups present in the territory (Healey 2007). The territory, on the other hand, hosts the socio-material manifestations of former and co-existing paths created by the agency of changing regimes. Agency can be included or excluded by narratives, visions and agendas and can also change with local conditions. Transforming urban spaces, e.g. into forms of green spaces, can increase residents' control of these spaces (Oswalt et al. 2013; Schilling \& Logan 2008; Siebel \& Häußermann 1987); and the dominant approach of development often impairs such agency by reducing 'dwellers to consumers, and the territory to a mere physical support' (Albrechts et al. 2020). To sum up, the dynamics of the three dimensions continuously interact and offer windows of opportunity for path change.

In addition to these three fundamental dimensions, one cross-cutting mode of thinking is characteristic of contemporary development strategy-making, namely the

Table 1. Different levels of emergence of strategy (with examples)

\begin{tabular}{|c|c|c|c|}
\hline $\begin{array}{l}\text { Levels of } \\
\text { emergence }\end{array}$ & Temporal & Agential & Spatial \\
\hline \multirow[t]{3}{*}{ High } & $\begin{array}{l}\text { Path vision } \\
\text { knowledge industry, ageing } \\
\text { friendly city }\end{array}$ & $\begin{array}{l}\text { Unspecific form } \\
\text { institutional capacity, social } \\
\text { capital }\end{array}$ & $\begin{array}{l}\text { Overall character } \\
\text { polarisation, cohesion }\end{array}$ \\
\hline & $\begin{array}{l}\text { Objectives / Milestones } \\
\text { bousing renewal, employment } \\
\text { generation }\end{array}$ & $\begin{array}{l}\text { Arenas of interaction } \\
\text { service co-production } \\
\text { arrangements, revenue, laws }\end{array}$ & $\begin{array}{l}\text { Model / structure } \\
\text { land use restructuring, inward } \\
\text { downsizing }\end{array}$ \\
\hline & $\begin{array}{l}\text { Tactics } \\
\text { DIY temporal use, tax incentives }\end{array}$ & $\begin{array}{l}\text { Single form of relations } \\
\text { participation in projects, } \\
\text { earmarked funding }\end{array}$ & $\begin{array}{l}\text { Single location changes } \\
\text { land use re-purposing, building } \\
\text { demolition }\end{array}$ \\
\hline Scale-free & $\begin{array}{l}\text { Principles } \\
\text { liveability }\end{array}$ & $\begin{array}{l}\text { Principles } \\
\text { social inclusion }\end{array}$ & $\begin{array}{l}\text { Principles } \\
\text { efficient land use }\end{array}$ \\
\hline
\end{tabular}


embedding of local level strategies in the multiple layers of higher-level interdependencies. In other words, the local level makes strategies on local territory, but with the intention to react to or shape conditions on supra-local scales by leveraging relations with other places and levels. This kind of relational thinking is key to strategic planning and governance (Healey 2007) and to competitiveness-building (Sorkin 1984). For shrinking cities, this is necessitated by the global drivers of shrinkage (Martinez-Fernandez et al. 2012).

At different levels of emergence, strategies are captured or formulated with constructs of different levels of abstraction on the three dimensions (Table 1.): on the temporal dimension, ranging from vision to tactics; on the agency dimension, ranging from institutional capacity to participation in specific projects; and on the spatial dimension, ranging from cohesion to land use re-purposing; and principles, which are scale-free.

\section{Sustainable shrinkage and growth-oriented strategies}

This section explores how shrinking city discourse translates into strategy-making frames, including three frames of the temporal, agential, and spatial dimensions and one cross-cutting frame of higher-level interdependencies (summarised in Table 2). To illustrate the main points in sustainable shrinkage strategies, this paper has named some contrasting points with growth-oriented frames. Admittedly, growth-oriented planning can also incorporate sustainability principles, but shrinking city discourse proposes something that can be more productive for development strategies. That is, to manage population shrinkage and its effects in turning the shrinkage trajectory into a sustainable development path, whereas growth-assuming and growth-conditioned rationales rely on growth as a precondition to achieving sustainability. Shrinking city discourse also does not assume that shrinkage-oriented approaches are automatically sustainable for a city, because the aim should be sustainability or other concepts representing genuine progress (Sousa \& Pinho 2015). Therefore, the following comparison is not a 'symmetric' comparison such as between planning aimed for shrinkage and planning aimed for growth, but serves more to illustrate the thinking behind sustainable shrinkage strategies.

\section{The temporal frame}

In the temporal dimension, strategy-making is about arranging thoughts and actions of various time frames into a desirable path. The temporal logic of path-steering can be viewed in terms of time frames and cross-frame principles: objectives are structural transformations in the medium term, pulled by long-term vision and goals, and supported by actions creating a stable basis in the present while principles are directions that transcend time frames (Gáspár 2011). Through these temporal strategic constructs, causal knowledge about internal and external conditions of development is channelled into strategies.

Strategic thinking in sustainable shrinkage recognises the global-level drivers of local structural change, including global economic processes, demographic transition and the transition to a low-carbon, more equal society (see Section 2.2). It 
Table 2. Comparing strategic frames of sustainable shrinkage and growth orientation

\begin{tabular}{|c|c|c|c|}
\hline \multicolumn{2}{|c|}{ Dimensions } & Sustainable shrinkage frames & \multirow[t]{2}{*}{ Growth-oriented frames } \\
\hline \multirow[b]{3}{*}{ 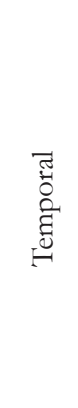 } & Function & Shaping thinking and actions over time into a desirable path & \\
\hline & Accentuation & Quality under no growth & Competitiveness under growth \\
\hline & $\begin{array}{l}\text { Landing } \\
\text { points }\end{array}$ & $\begin{array}{l}\text { - Demographic transition, global } \\
\text { processes and regional context; } \\
\text { - Ordinary city, a smaller population, } \\
\text { higher quality of life; } \\
\text { - Structural transformations; } \\
\text { - Supporting everyday life; learning; } \\
\text { making collective strategies; } \\
\text { - Flexible, learning- and community- } \\
\text { based incremental change }\end{array}$ & $\begin{array}{l}\text { - Technology and market trends, } \\
\text { stories of successful big cities; } \\
\text { - Competitive city, a larger, wealthier } \\
\text { population, more economic assets; } \\
\text { - Asset and capital accumulation; } \\
\text { - Symbolic projects and marketing; } \\
\text { learning; making plans; } \\
\text { - Efficient implementation of projects } \\
\text { and targets to match rapid changes }\end{array}$ \\
\hline \multirow[b]{3}{*}{ 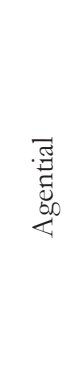 } & Function & \multicolumn{2}{|l|}{ Cultivating and channelling agency } \\
\hline & Accentuation & Inclusion of non-economic capital & Inclusion of growth-driving capital \\
\hline & $\begin{array}{l}\text { Landing } \\
\text { points }\end{array}$ & $\begin{array}{l}\text { - Public funding; } \\
\text { - Knowledge of sustainability, } \\
\text { shrinkage and local resources; } \\
\text { concepts framing shrinkage; } \\
\text { downsizing instruments; } \\
\text { - Broader agenda; participation beyond } \\
\text { consensus-building }\end{array}$ & $\begin{array}{l}\text { - Private capital; } \\
\text { - Knowledge of market trends and } \\
\text { successful growth models; concepts } \\
\text { framing growth; planning gain } \\
\text { instruments; } \\
\text { - Growth coalition agenda; } \\
\text { participation to negotiate terms of } \\
\text { growth }\end{array}$ \\
\hline \multirow[b]{3}{*}{ 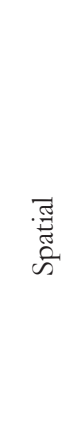 } & Function & \multicolumn{2}{|l|}{ Shaping accumulated changes on the territory } \\
\hline & Accentuation & $\begin{array}{l}\text { Reducing quantity; qualitative, balanced } \\
\text { development; local resources }\end{array}$ & $\begin{array}{l}\text { Increasing assets and supply; selective } \\
\text { development; external resources }\end{array}$ \\
\hline & $\begin{array}{l}\text { Landing } \\
\text { points }\end{array}$ & $\begin{array}{l}\text { - Downsizing, stronger regulation; } \\
\text { - Quality improvement for everyone; } \\
\text { - Land conversion to lower economic } \\
\text { but higher social and ecological value; } \\
\text { - Building inward to make the existing } \\
\text { city compact; existing stock upgrade; } \\
\text { - Balanced, coordinated development; } \\
\text { - Local resources drive development } \\
\text { and place-based economies }\end{array}$ & $\begin{array}{l}\text { - Increasing attractive assets; } \\
\text { - More supply at minimum quality; } \\
\text { higher quality for attractive sites; } \\
\text { - Value-adding land conversion; } \\
\text { - Developing new sites compactly; } \\
\text { adding higher quality stock; } \\
\text { - Focusing on prime sites; triage; } \\
\text { - External resources drive } \\
\text { development and economy }\end{array}$ \\
\hline \multicolumn{4}{|c|}{ Cross-cutting frame: Higher-level interdependencies } \\
\hline & Function & \multicolumn{2}{|l|}{ Addressing relations with other places } \\
\hline & Accentuation & Collaboration, compromise, local users & Collaboration, competition, desirable users \\
\hline & $\begin{array}{l}\text { Landing } \\
\text { points }\end{array}$ & $\begin{array}{l}\text { - In functional space, socio-technical } \\
\text { infrastructure re-organisation; intra- } \\
\text { regional agreement; } \\
\text { - Stemming outmigration to growing } \\
\text { regions by attending to local users; } \\
\text { alliance with other shrinking cities }\end{array}$ & $\begin{array}{l}\text { - In functional space, socio-technical } \\
\text { infrastructure organisation; intra- } \\
\text { regional competition; } \\
\text { - Competing for desirable groups with } \\
\text { other growing regions; shrinking } \\
\text { cities as sources for growth pressure }\end{array}$ \\
\hline
\end{tabular}


embraces the vision of a city with a smaller, older population, which nevertheless has a higher quality of life and its own identity (Popper \& Popper 2002). Without the pressure to attract growth for development and to provide more services, shrinking cities can devote resources to improving the quality of public services and the built environment and make social progress (Hirt \& Beauregard 2019; Siebel \& Häußermann 1987; Sousa \& Pinho 2015). Growth-oriented planning, on the other hand, focuses on increasing the quantity of services, infrastructure and competitiveness assets, because it expects growth and takes it as a necessary condition for urban development. The linear growth model assumes that the population will keep growing and that fluctuation is correctable with further growth stimulation (Banzhaf et al. 2006), which fits in the historical development of urbanisation and de-ruralisation. The urban life-cycle model based on the dynamics of population flow between urban areas in a region (van den Berg et al. 1982; Wolff 2018) views population change as a result of consumer choices based on each locale's attractiveness. Following this logic, cities should restructure themselves to be economically competitive - especially towards knowledge-based industries - in order to halt or prevent decline (Bontje 2004; Wiechmann \& Bontje 2015; Zakirova 2010). However, this model is ineffective for many shrinking cities due to global economic processes and differences in regional conditions (Cunningham-Sabot et al. 2013; Kinossian 2018; Wolff 2018).

In strategy-making processes, the point of the present is where pressure to take immediate action often undermines the effort to formulate well thought-through collective strategies and contributes to boom-and-bust cycles (van Assche et al. 2020). Supporting liveability, social welfare and maintaining the quality of urban environment, can stabilise remaining population (A. Haase et al. 2014; Hartt 2018; Pallagst, Fleschurz \& Said 2017), which creates a stable basis for learning, experimenting and building up governance capacity; while knee-jerk reactions to reverse depopulation before the complex drivers are understood as often counter-productive (Hollander \& Popper 2011).

In the medium term, structural transformation needs to address social, economic and urban environment issues to achieve sustainable development (Bernt et al. 2012). It takes a different course than that traditionally applied to urban decline propelling rapid development of competitive assets with capital injection, attracting creative class and external investments over slow endogenous socio-economic regeneration (e.g. Hartt \& Warkentin 2017; Stryjakiewicz et al. 2018). For the many shrinking cities with limited resources and no large sums of external funding, restructuring needs to be a gradual change through social and cultural regeneration, social innovation and local agency (Kinossian 2018). Reorganising socio-technical infrastructures is necessary to regain liveability in cases of substantial depopulation, but right-sizing and redevelopment should not become a standard quick cure, because they could shift problems onto the vulnerable population (Audirac 2018; Kirkpatrick 2015) and undermine the search for more proactive strategies.

The approach of path-steering is inseparable from the structural nature of shrinkage. Firstly, structural transformation takes time, therefore continuous support for 
everyday liveability and social stability is an important basis of development. Secondly, the task of development is qualitative transformation, unlike in growth situations where solving quantitative shortages is always the challenge. Qualitative transformations involve more than just changes on urban space and require learning and reflection on existing approaches and strategies. Finally, given the long-term nature of the shrinkage trajectory, responding to short-term fluctuations requires flexible and experimental approaches to avoid wasteful developments (van Assche et al. 2020; Wiechmann 2008a).

\section{The agential frame}

In the agential dimension, strategy-making is about cultivating and channelling embedded and distributed agency to drive urban development. Such agency critically depends on means and instruments, social capital, and knowledge and tools. Shrinkage is often considered 'intractable' (Wiechmann \& Bontje 2015: 2), because these variables have dramatically changed from those under conditions of growth.

In a growth environment, planning can leverage private capital for public work, such as upgrading public facilities and expanding housing. Planning instruments are designed to restrict growth activities and negotiate planning gains (Crook et al. 2015; Logan \& Molotch 2007). Although these benefits are not always viable in the long term or enough to offset negative impacts of growth, the increasing number of jobs and local facilities create a favourable political environment, justifying growth-oriented strategies (Troutman 2004).

In contrast, shrinking cities have diminished financial means because of shrunken revenue basis and rising per capita expenditure (Hudeček et al. 2019; Mäding 2004). In addition to lack of means, political pressure to achieve regrowth is high, further preventing productively confronting shrinkage (De Groot 2019; Mallach 2017). Cities resort to 'classical strategies' of competing for businesses and middle class residents (Martinez-Fernandez et al. 2016), but these strategies compete for the limited resources also needed for supporting liveability and social welfare in order to stabilise the remaining population (A. Haase et al. 2014; Pallagst, Fleschurz \& Said 2017). Therefore, financial support from higher-level government is essential for stemming a downward spiral and creating some room for adaptation. However, this does not mean that injecting large amounts of public capital in regeneration is necessarily the best strategy for the increasing number of shrinking cities: on the one hand, because public resources are limited and on the other hand, because speculative developments and economies without an endogenous basis could lead to another boom-and-bust cycle and future costs for adaptation (cf. Siedentop \& Fina 2010; Kinossian 2018; Rink et al. 2012).

Therefore, financial means alone without strategic re-orientation are not enough. Knowledge of urban shrinkage is needed to confront the reality of shrinkage, create mobilising concepts and guide long-term development (Hall 2009; Jessen 2012; Pallagst, Fleschurz \& Said 2017). Knowledge of sustainable development is key to operating urban regeneration projects; and learning agencies are often conducive to successful long-term development (Bernt et al. 2012). Without learning and conscious re-orientation, capital injection 
could undermine the path towards a sustainable future and draw growth-dependent interests back into the planning process (Berglund 2020; Stryjakiewicz et al. 2018). Re-assessing existing planning instruments is also a key adaptation process and should include the information system for managing fixed assets, supply-focused land development planning, and instruments for coordinated downsizing and land re-purposing (Bernt 2009; Hackworth 2014; Jonsson \& Syssner 2018; Kübler et al. 2012).

In times of growth, involved actors possess capital for an agenda already set for growth. Everyday services are supplied through infrastructure. When growth pressure is lacking, the agenda can no longer be limited to growth and supply increases. Civil society can often play an instrumental role, given the difficult decisions in the right-sizing process (Elzerman \& Bontje 2015; Hollander \& Németh 2011), the need to solve problems with small stakeholders (Radzimski 2018), the benefits of social solutions for liveability (A. Haase et al. 2012; Murtagh 2016; Ročak et al. 2016a), and the challenge of building a self-sustainable future through local innovations (Grillitsch \& Sotarauta 2018; Kinossian 2018). Thus, civic engagement goes beyond negotiating consensus on terms of growth. It also involves co-producing narratives, day-to-day solutions for quality of life, and long-term learning and innovation networks. But while the civic domain is adversely affected by shrinkage, there might not be much bottom-up power to contribute unless financial and organisational support are provided to activate social capital (A. Haase et al. 2012; Ročak et al. 2016a; Steinführer et al. 2014; Strohmeier \& Bader 2004).

\section{The spatial frame}

In the spatial dimension, strategy-making is about negotiating changes between topdown and bottom-up forces and shaping their accumulated effects on the territory. In contrast to 'fetishization' of growth and expansion in growth-oriented practices (Hamilton 2003; Kirkpatrick 2015: 272), planning for urban shrinkage requires planning for less - fewer people, fewer buildings, fewer land uses (Popper \& Popper 2002). This includes downsizing of over-dimensioned infrastructure, greening abandoned urban spaces and proactively restricting the amount of development. But in the long term, qualitative development is more important than quantitative targets. It can point to four things:

Firstly, it is about improving the experiential quality of urban living. Under population pressure cities have to provide more urban services at minimum standard but shrinking cities can use the opportunity to catch up in their quality of public services, affordable housing, green spaces, and cultural and social environment (Hirt \& Beauregard 2019; Sousa \& Pinho 2015). These objectives can also be found on a growth-oriented agenda (e.g. in smart growth). But in a growth-oriented, competitiveness-building logic, investment focuses on assets for quality of life in places that can attract more middle and creative classes, instead of on areas that are most in need.

Secondly, qualitative development is about restructuring the functions of urban spaces. While growing cities carry out use-intensifying and value-adding developments and accumulate attractive infrastructural assets, shrinking cities have to come to terms with the fact that their 
main trend is spatial development in just the opposite direction - for example, downsizing neighbourhoods, decommissioning industrial terrain, reducing residential and commercial use to green space use (Pallagst, Fleschurz \& Trapp 2017). But the reduction in economic value should be considered alongside the increase of social and ecological value. The latter can offer a unique opportunity to improve cities in ways the growth context lacks (Schilling \& Logan 2008).

Thirdly, qualitative development is about remaking the spatial structure for more compact, more liveable cities. De-densification of settlement and/or sprawl development can impair the viability of socio-technical infrastructure and liveability in the long term (Hudeček et al. 2019; Moss 2008; Siedentop \& Fina 2010; Slach et al. 2019). Therefore, shrinking cities should build inward and enhance the spatial efficiency of existing urban areas and building stock, through more regulation, in-filling before expansion, and upgrading before replacing (Kübler et al. 2012; Müller $\&$ Siedentop 2004). While compactness is also a principle for growth-oriented planning, it is often not the guiding goal, but is used to minimise the impact of expansions positioned based on economic potential.

Finally, qualitative change is about re-balancing the territory. This means not exacerbating socio-spatial inequality with selective (dis)investment and gentrification strategies (Aalbers \& Bernt 2019; Ehrenfeucht \& Nelson 2020; Fol 2012). A city-wide framework is crucial to coordinating projects and eventually a balanced development (Strauß 2012). Pointing out the danger of centralised, rationally planned downsizing and triage measures, researchers argue for neighbourhood self-determination for a socially sustainable downsizing (Hollander \& Németh 2011), and questions are raised about whether aggressive right-sizing as a quick cure, is necessarily the best model (Audirac 2018; Kirkpatrick 2015).

In neoliberal growth-oriented planning, the focus is on attracting external capital, and local territory is a receptacle for capital and a transplanted knowledge sector. But shrinking cities need to re-focus on local resources because they are disconnected from capital flows in the global economy (Martinez-Fernandez et al. 2012; Pallagst, Fleschurz \& Said 2017). The local territory should be seen as active socio-spatial networks that host natural, social and cultural resources, and as a basis for quality of life, local innovations, and place-based economies (Kinossian 2018; Ročak et al. 2016a; Schilling \& Logan 2008). The rediscovery of the bottom-up potential of the territory can open up pathways towards a more self-sustainable future (Albrechts et al. 2020).

\section{The frame of higher-level interdependencies}

Even as local planning is administratively bound to a specific territory, it must act strategically, keeping in mind its interdependencies with other cities and regions on higher levels. Thus, development strategy-making constantly involves the cross-cutting frame of higher-level interdependencies.

Interdependencies based on spatial adjacency are often addressed in strategic spatial planning. Physical processes that connect urban areas are manifestations of functional relatedness; therefore, these areas viewed together provide a crucial frame for balanced 
development (Davoudi 2008; Healey 2009). Shrinking cities are embedded in functional (city) regions through their socio-technical infrastructure networks, and the task of re-organising these infrastructures can only be approached from this level (Müller \& Siedentop 2004). Centrality-based systems and inter-municipal sharing are used to plan service distribution so as to keep them sustainable and accessible, at least on the regional level (Melis 2013; Rutgers-Zoet \& Hospers 2018).

Interdependencies of spatial adjacency can also be found in inter-city competition, which can pose a threat to sustainable land use. Competition under growth pressure can be 'healthy', but in times of population shrinkage, it can be 'ruinous' and a 'zero-sum game' (Kübler et al. 2012; Mäding 2004; Nuissl \& Rink 2005). Realising this, cities in shrinkage-expecting regions make bottom-up regional agreements to distribute growth opportunities in order to reduce internal competition and development risks (e.g. Humer 2018; Provincie Noord-Holland 2017a, 2017b).

Many interdependencies of shrinking cities have no spatial adjacency. The relational view of places has made clear that many of the strongest change drivers go beyond the physical territory (Amin 2004; Massey 2005) - for example, the cross-continental relation between shrinking Polish cities and the growing city of London (Bernt 2016). The relation between growing and shrinking cities is a crucial one for strategic thinking, because growth and shrinkage are two faces of the same 'global' coin: most contemporary urban shrinkage is a product of global processes (Cunningham-Sabot et al. 2013; Martinez-Fernandez et al. 2012). But also for the sustainability 'face', polarisation between shrinking and growing places causes concern for regional equality (Bock 2019), territorial cohesion (De Groot 2019; Rodríguez-Pose 2018), and the environment carrying capacity and liveability of growing regions.

Shrinking cities' relations with other shrinking cities are promising yet under-developed. Lobbying for top-down policies such as the German national programme 'Stadtumbau Ost' owes its effectiveness to the revealing of the scale and prevalence of shrinking cities (Bernt et al. 2014). Peripheralisation theories distinguish the peripheral shrinking cities as a group that need different development approaches (Leick \& Lang 2018). However, so far local initiatives to make strategic connections have concentrated on cultural movements such as the slow-food and other slow-world activities (Sousa \& Pinho 2015), while knowledge exchange and strategic alliances in areas of adaptive strategies, bio-economy, and local innovations have untapped potential.

In short, local strategic framing of interdependencies can help avoid place-centrism (Jessop et al. 2008), foster the development of more effective policy instruments and pave the way towards sustainability on multiple scales.

\section{Directions towards sustainability}

The frames presented in the previous section summarise the main claims and reasoning underlying the proposed approaches and strategies in the shrinking city discourse, but what directions do they offer for a local strategic re-orientation? What strategy-making approach is necessary to bring transformative rationales and frames into action? 


\section{Rationales under a critical sustainability}

This section explicates the multi-facetedness of sustainability to create a clearer perspective on the multitude of shrinking city strategies. Shrinkage is a trajectory for longterm development strategies and sustainability can be the guiding principle. However, despite being a universally embraced value, there is no universal definition of sustainability (Section 2.2). It works more as a framing device for reasoning, channelling values and principles into specific contexts to generate strategic rationales. Starting from different temporal, spatial and social parameters, one can arrive at different kinds of sustainability, and consequently, different strategic rationales and strategies.

The sustainability of everyday life is expressed in concepts such as liveability, equal living conditions, quality of life, and well-being (Hall 2009; Hollander 2011; Pallagst, Fleschurz \& Trapp 2017; Slupina et al. 2019: 25). However, in what ways should they be supported? Should policies aim to return to the pre-shrinkage model of living, or models of other more competitive cities? The sole focus on basic needs for living is contestable from the perspective of the sustainability of the city as a place, because the latter also considers questions like how individuals are bonded in a community, how they are bonded to their city to form a sense of attachment and stewardship, and how the community exists and evolves. From the perspective of planetary sustainability, a critical reflection is required on the pre-existing model of consumption lifestyles conditioned by modern urbanity and capitalist economies (Huber 2013; Lehtinen 2018), a forced continuation of uniform living standards and ubiquitous infrastructure at the expense of resources and social justice (Graham \& Marvin 2001; Kirkpatrick 2015), and the relations between humanity and nature that have been chronically sidelined in modern urbanisation history.

The sustainability of the city as a place stresses qualities that will allow the place to remain robust, such as place qualities, future strength, and self-sustainability (Albrechts et al. 2020; Bock 2019; Healey 2007). This view argues that only everyday liveability is not enough, because longterm issues such as opportunities for the younger generations, as well as human and social capital are key to the continued existence of the city. However, in a neoliberal politico-economic environment, to remain robust inevitably means to stay competitive in the inter-city competition (Kreichauf 2014). This could collide with the other two facets of sustainability in shrinking cities, as difficult choices arise between investing in struggling neighbourhoods and investing in economic assets, between supporting disadvantaged groups and attracting creative classes, and between experimenting with new forms of economy and adopting existing models as fast solutions. Transformative positions stress the social and cultural qualities of the community, collective self-reliance, local innovation, and an alternative policy agenda instead of simply 'catching up' (Friedmann 1987; Kinossian 2018; Magnaghi 2005; Moulaert et al. 2005). But what does transformation mean for the city? What essence of urbanity must be preserved - is it the lifestyle under a modern infrastructural ideal (Graham \& Marvin 2001), the places for production and distribution (Harvey 2010), or communities of socio-cultural creativity (Jacobs 2016)? 
The sustainability of the (planetary) socio-ecological system is often discussed in terms of resilience, resource efficiency, social justice, and wider welfare which depend on fundamental societal changes in the models of economy, urbanisation, and consumption lifestyles (on transitional discourses, see Escobar 2015). Among them, degrowth and postgrowth tend to counter local political ambitions of making progress with conventional growth levers, such as attracting global industries, gentrification, infrastructure expansion, and neighbourhood redevelopments (Lehtinen 2018; Schulz 2018). For many shrinking city policy-makers, these levers are, however, the few available options to maintain quality of everyday life as well as individuals' livelihood and future prospects (Eisinger 1988; Kreichauf 2014; Rousseau 2009). Although shrinking cities could provide conditions for progressive ideas and communities and could become fertile ground for innovations towards planetary sustainability (Reverda et al. 2018), a drastic break away from existing economic and institutional models could jeopardise the other two types of sustainability under current economic, institutional and cultural circumstances, leading to the collapse of the community without giving it room to evolve. Therefore, the critical question for the local level is, where, when and how would the visions for the planetary interests be aligned with the interests of local lives and communities?

The concept of sustainability has multiple facets that can lay conflicting claims to strategy-making. However, this inner tension mirrors the tensions in the reality of local planning in shrinking cities, which makes it potentially an effective conceptual device for critical strategic thinking.
Shrinking cities are found in diverse local contexts, with different needs for development despite their shared characteristic of losing population. A strategic approach to sustainability would be to pursue the kinds of sustainability favoured by circumstances, on the condition that this does not impair the possibilities of pursuing other kinds of sustainability. This paper proposes thinking in terms of a strategic connection between sustainability and local conditions: Shrinking cities' demographic and social profiles as well as their collective lifestyles are changing. Focusing on quality of life, especially for groups that have been overlooked in strategic processes, could create a unique living environment for the benefit of the people and the place.

Some shrinking cities experience largescale spatial transformations of industrial, commercial, and/or residential areas. As a whole, the city's economic infrastructure shrinks, but that makes room for the growth of green and social infrastructures - infrastructure in both hard and soft forms that support multi-purpose public use and are managed by the public as a whole, including green spaces as well as social and cultural organisations. These can be coupled with the development of low-productivity sectors, "as a form of social organisation embedded in the community, working in harmony with nature to deliver the capabilities that allow us to prosper" (Jackson 2016: 158). For example, green infrastructure (Schilling \& Logan 2008), social economy (Murtagh 2016) and neighbourhood cultural centres (A. Haase et al. 2012). Thus, the transformations driven by global processes can be turned into alternative place developments and community resilience-building, but this requires recognition and support by higher-level policies. 
Finally, shrinking cities can make contributions to sustainability on a larger scale in both place-bound and transferrable ways. By resisting conventional development logics, they can preserve unique natural resources, cultural heritage, and environment-friendly lifestyles (Kinossian 2018). They can use their unique socio-spatial settings to generate social innovations, from new forms of socio-technical infrastructure to new forms of business adapted to the conditions and needs of a shrinkage trajectory, which would be valuable as alternatives to capital-driven urban development (Coutard \& Rutherford 2010; Murtagh 2016). They can also, as a region, improve the local quality of life and stabilise the local population and contribute to supra-regional sustainability by reducing pressure on growing regions' socio-ecological systems. These contributions can be turned into positive impulses that compensate the economic disadvantages of shrinking cities - if higher-level policies are made to acknowledge and support their value.

\section{Approaches to strategy-making}

Shrinking cities face challenges that require not only new development rationales and strategies, but also new approaches to generate rationales and strategies. A strategy-making perspective (Section 3) can enrich the discussion on procedural aspects of transformative planning already started in governance and strategic planning theories.

Firstly, sustainable shrinkage ideology faces resistance from the practical side. The former stresses the need for 'accepting shrinkage', 'planning for decline', and prioritising liveability (Hollander \& Popper 2011; Hospers 2014; Pallagst, Fleschurz \&
Said 2017). For some post-industrial cities, rather than relying on huge investments for survival, it may be more realistic to shrink to a population sustainable by a deindustrialised local economy (Constantinescu 2012). The competitiveness-building model is questioned, especially in the context of non-core regions, where it might not work at all in attracting growth or benefiting the local community in the long run (Kinossian 2018; Leick \& Lang 2018). However, the growth-oriented vision is aligned with residents' top concern - economic revival, rather than liveability-related and environmental policies, especially among young people (Panagopoulos et al. 2015). Residents and politicians fear losing public services if they do not regrow (Schatz 2017). Clearly, 'accepting shrinkage' or 'degrowth' would be hard to accept for communities longing for improvement to their economic welfare. Compared to rural settlements, urban settlements have a higher density of population and more conflicting demands on urban resources, which can make collective actions more difficult (Aalbers \& Bernt 2019; Bernt 2009). Under these conditions, it would be challenging to reach full consensus on a vision and agenda in the interests of all kinds of sustainability.

However, this does not mean strategies are not possible. In social strategy-making, actors do not always aim for a unified goal, but act on concrete issues where they can agree (Braybrooke \& Lindblom 1963). Avoiding contentious goal-setting may provide a window of opportunity to preserve an alternative agenda for sustainability in an overall neoliberal environment. Bernt (2009) reported how in cases of drastic shrinkage, when the need for intervention is aligned with financial instruments, local actors form coalitions for downsizing, but 
the difficulties in achieving implementable plans can eventually lead to the dissolution of such coalitions. In fragmented socio-spatial conditions, the 'perspective incrementalism' approach used for the post-industrial region Emscher provides a reference for incrementally generating large-scale transformations. It focuses on creating concrete projects, and uses an instrument-oriented instead of a programme-oriented approach, guided by an overall vision of comprehensive plans (Karl et al. 1993; Wiechmann 2008b: 53-56).

In regard to further turning good practices into positive momentum for change, van Assche et al. (2020) propose institutional capacity-building through consciously experimenting, learning, and re-tooling, while maintaining a long-term perspective. The 'bricolage' process behind Danish wind energy infrastructure development (Garud \& Karnøe 2003) provides a possible model for governing bottom-up innovation: the path evolves through integration of distributed innovations and in turn becomes the environment of the actors, further enhancing the directions of development. This (meta) strategy critically depends on flexibility, communication, collective learning, and incorporating what is learned on the institutional level. In this way, the institutional environment can become increasingly favourable for more substantial strategies for sustainability.

\section{Conclusion and further research}

Shrinking cities' strategy-makers could benefit from more clarity on the guiding principles for development in their situations and draw from strategic frames and rationales that put empirical ideas into perspective. Therefore, alongside the proliferating empirical work supporting the call for a change of orientation and approach, much work remains to be done on conceptualisation and theorisation.

Firstly, sustainability cannot be taken for granted as a set of self-explanatory, coherent principles. The sustainable development goal for cities and communities of the UN and EU are explicitly set in the context of urbanisation. Clearly, there is a lack of knowledge and reinterpretation of sustainability in shrinkage trajectories, even though shrinking cities have their own significance for (un)sustainability. The tensions between the three facets of shrinking cities mirror the complexity of the reality of local planning in shrinking cities. A more nuanced and critical interpretation can provide strategy-makers with a reasoning device to navigate between general theories and local conditions and to construct development rationales.

In terms of theorisation, more reflection with consideration of other non-shrinkingcity perspectives and contexts is needed (Bernt 2016). To make a first step towards such reflection, this paper synthesises an overview of empirically grounded frames of urban development in the shrinking city discourse. It takes up the action-oriented, integrative perspective of local strategy-making to capture the challenges of the task and the need for more sensitivity to complex processes and agency, and their interaction in space.

Furthermore, to operationalise critical sustainability thinking for shrinking city development, more knowledge is needed on how rationales for sustainability differ in shrinking cities with different trajectories. Meanwhile, research needs to identify potential landing points in existing institutional 
processes for reinterpreting sustainability principles, renewing rationales and frames, and creating new strategy-making approach. Strategic spatial planning for example, needs to be tailored to the situation at hand (Albrechts 2015) because it has historically focused on growth contexts. With a lack of growth pressure and substantial external investment, planners need to reformulate their strategic frames, the focuses of planning (spatial assets, social groups, and ecological services), the approaches for more flexible strategies, and the instruments for information gathering and implementation.

Finally, development strategy-making is ultimately about 'deliberative paradigm change', that is, 'shifting and reshaping convictions' (Healey 1997: 244-245). In this sense, strategic concepts have major roles to play in de-stigmatising shrinkage through discourse and action. Therefore, research should engage in more active production of strategic concepts that channel academic knowledge into practice in order to drive a 'paradigm change'. But instead of expert-based conceptualisation, researchers need to draw from the social production of strategic concepts (van Duinen 2013) in order to accelerate an 'organic' social process to 'pack' sustainability values, strategic frames, and locally contextualised strategic rationales into concepts.

\section{Acknowledgements}

This project has received funding from the European Union's Horizon 2020 research and innovation programme under the Marie Skłodowska-Curie grant agreement No 813803. My sincere thanks also go to the editors and the two reviewers for their helpful comments on earlier drafts.

\section{References}

Aalbers, M. B., \& M. Bernt (2019). The political economy of managing decline and rightsizing. Urban Geography 40: 2, 165-173. doi:10.1080/ 02723638.2018 .1524654

Albrechts, L. (2004). Strategic (spatial) planning reexamined. Environment and Planning B: Planning and Design 31: 5, 743-758.

Albrechts, L. (2015). Ingredients for a more radical strategic spatial planning. Environment and Planning B: Planning and Design 42: 3, 510--525. doi:10.1068/b130104p

Albrechts, L., A. Barbanente \& V. Monno (2019). From stage-managed planning towards a more imaginative and inclusive strategic spatial planning. Environment and Planning C: Politics and Space 37: 8, 1489-1506.

Albrechts, L., A. Barbanente \& V. Monno (2020). Practicing transformative planning: the territory-landscape plan as a catalyst for change. City, Territory and Architecture 7: 1. doi:10.1186/ s40410-019-0111-2

Albrechts, L., P. Healey \& K. R. Kunzmann (2003). Strategic spatial planning and regional governance in Europe. Journal of the American Planning Association 69: 2, 113-129.

Alexander, E. R. (2000). Rationality revisited: Planning paradigms in a post-postmodernist perspective. Journal of Planning Education and Research 19: 3, 242-256.

Amin, A. (2004). Regions unbound: towards a new politics of place. Geografiska Annaler: Series B, Human Geography 86: 1, 33-44.

Audirac, I. (2018). Shrinking cities: An unfit term for American urban policy? Cities 75, 12-19.

Audirac, I., S. Fol \& C. Martinez-Fernandez (2010). Shrinking cities in a time of crisis. Berkeley Planning Journal 23: 1, 51-57.

Banzhaf, E., A. Kindler, \& D. Haase (2006). Monitoring and Modelling Indicators for Urban Shrinkage-The City of Leipzig, Germany. Center for Remote Sensing of Land Surfaces 28, 30.

Berglund, L. (2020). The Shrinking City as a Growth Machine: Detroit's Reinvention of Growth through Triage, Foundation Work and Talent Attraction. International Journal of Urban and Regional Research 44: 2, 219-247. doi:10.1111/14682427.12858

Bernt, M. (2009). Partnerships for demolition: The governance of urban renewal in East Germany's shrinking cities. International Journal of Urban and Regional Research 33: 3, 754-769.

Bernt, M. (2016). The Limits of Shrinkage: Conceptual Pitfalls and Alternatives in the Discussion of Urban Population Loss. International Journal of 
Urban and Regional Research 40: 2, 441-450. doi:10.1111/1468-2427.12289

Bernt, M., M. Cocks, C. Couch, K. Grossmann, A. Haase, \& D. Rink, (2012). Shrink smart. Policy response, governance and future directions. Research Brief 2.

Bernt, M., A. Haase, K. Großmann, M. Cocks, C. Couch, C. Cortese, \& R. Krzysztofik (2014). How does(n't) Urban Shrinkage get onto the Agenda? Experiences from Leipzig, Liverpool, Genoa and Bytom. International Journal of Urban and Regional Research 38: 5, 1749-1766. doi:10.1111/1468-2427.12101

Bock, B. B. (2019). Van leefbaarheid naar toekomstkracht: inspiratie voor een nieuw krimpbeleid. In Land in Samenhang: Krimp en regionale kansengelijkheid. The Hague: Ministry of the Interior and Kingdom Relations.

Bontje, M. (2004). Facing the challenge of shrinking cities in East Germany: The case of Leipzig. GeoJournal 61: 1, 13-21. doi:10.1007/s10708004-0843-7

Braybrooke, D., \& C. E. Lindblom (1963). Strategy of decision; policy evaluation as a social process. Political Science Quarterly 79: 4, 584-588.

Bryson, J. M. (1988). A strategic planning process for public and non-profit organizations. Long Range Planning 21: 1, 73-81. doi:10.1016/00246301(88)90061-1

Constantinescu, I. P. (2012). Shrinking cities in Romania: Former mining cities in Valea Jiului. Built Environment 38: 2, 214-228. doi:10.2148/ benv.38.2.214

Coutard, O., \& J. Rutherford (2010). The rise of post-networked cities in Europe? Recombining infrastructural, ecological and urban transformations in low carbon transitions. In Bulkeley, $\mathrm{H}$., S. Marvin, V. Castan Broto \& M. Hodson (eds.): Cities and low carbon transitions, 123-141. Routledge, Abingdon.

Crook, T., J. Henneberry, \& C. Whitehead (2015). Planning gain: Providing infrastructure and affordable housing. John Wiley \& Sons, Hoboken.

Cunningham-Sabot, E., I. Audirac, S. Fol \& C. Martinez-Fernandez (2013). Theoretical approaches of "shrinking cities". In Wiechmann, T., K. Pallagst, C. Martinez-Fernandez (eds.): Shrinking Cities: International Perspectives and Policy Implications, 14-30. Taylor and Francis, Oxfordshire.

Czarniawska, B., \& P. Gagliardi (2003). Narratives we organize by (Vol. 11). John Benjamins Publishing, Amsterdam.

Davoudi, S. (2008). Conceptions of the city-region: a critical review. Proceedings of the Institution of Civil Engineers-Urban Design and Planning 161: 2, 51-60.
Dax, T., \& M. Fischer (2018). An alternative policy approach to rural development in regions facing population decline. European Planning Studies 26: 2, 297-315. doi:10.1080/09654313.2017. 1361596

De Groot, H. L. F. (2019). Groei en krimp; uitdagingen voor governance en solidariteit. In Land in Samenhang: Krimp en regionale kansengelijkheid. The Hague: Ministry of the Interior and Kingdom Relations.

Dubeaux, S., \& E. Cunningham-Sabot (2018). Maximizing the potential of vacant spaces within shrinking cities, a German approach. Cities 75, 6-11. doi:10.1016/j.cities.2017.06.015

Ehrenfeucht, R., \& M. Nelson (2020). Just revitalization in shrinking and shrunken cities? Observations on gentrification from New Orleans and Cincinnati. Journal of Urban Affairs 42: 3, 435-449.

Eisinger, P. K. (1988). The rise of the entrepreneurial state: State and local economic development policy in the United States. University of Wisconsin Press, Madison.

Elzerman, K., \& M. Bontje (2015). Urban Shrinkage in Parkstad Limburg. European Planning Studies 23: 1, 87-103. doi:10.1080/09654313. 2013.820095

Fol, S. (2012). Urban shrinkage and socio-spatial disparities: Are the remedies worse than the disease? Built Environment 38: 2, 259-275. doi:10.2148/benv.38.2.259

Friedmann, J. (1987). Planning in the Public Domain: From Knowledge to Action. Princeton University Press, New Jersey.

Friedmann, J. (2004). Strategic spatial planning and the longer range. Planning Theory \& Practice 5: 1, 49-67.

Garud, R., \& P. Karnøe (2001). Path Dependence and Creation. Taylor \& Francis, Oxfordshire.

Garud, R., \& P. Karnøe (2003). Bricolage versus breakthrough: distributed and embedded agency in technology entrepreneurship. Research Policy 32: 2, 277-300.

Garud, R., A. Kumaraswamy \& P. Karnøe (2010). Path dependence or path creation? Journal of management studies 47: 4, 760-774.

Gáspár, T. (2011). Path dependency and path creation in a strategic perspective. Journal of Futures Studies 15: 4, 93-108.

Graham, S., \& S. Marvin (2001). Splintering urbanism: networked infrastructures, technological mobilities and the urban condition. Psychology Press, Hove.

Grillitsch, M., \& M. Sotarauta (2018). Regional growth paths: From structure to agency and back. Papers in Innovation Studies 1, 1-23. 
Großmann, K., M. Bontje, A. Haase \& V. Mykhnenko (2013). Shrinking cities: Notes for the further research agenda. Cities 35, 221-225.

Haase, A., G.-J. Hospers, S. Pekelsma \& D. Rink (2012). Shrinking areas: Front-runners in innovative citizen participation. European Urban Knowledge Network, The Hague.

Haase, A., D. Rink, K. Grossmann, M. Bernt, \& V. Mykhnenko (2014). Conceptualizing urban shrinkage. Environment and Planning A: Economy and Space 46: 7, 1519-1534. doi:10.1068/ a46269

Haase, D. (2008). Urban ecology of shrinking cities: An unrecognized opportunity? Nature and Culture 3: 1, 1-8. doi:10.3167/nc.2008.030101

Hackworth, J. (2014). The limits to market-based strategies for addressing land abandonment in shrinking American cities. Progress in Planning 90, 1-37. doi:10.1016/j.progress.2013.03.004

Hall, H. M. (2009). Slow growth and decline in Greater Sudbury: challenges, opportunities, and foundations for a new planning agenda. Canadian Journal of Urban Research 18: 1, 1-26.

Hamilton, C. (2003). Growth Fetish. Allen \& Unwin, Sydney.

Hartt, M. (2018). How cities shrink: Complex pathways to population decline. Cities 75, 38-49.

Harvey, D. (2010). Social justice and the city. University of Georgia Press, Athens.

Hay, C. (1995). Structure and agency. In Stoker, G. \& D. Marsh (eds.): Theory and methods in political science, 189-207. Macmillan, London.

Healey, P. (1997). Collaborative planning: Shaping places in fragmented societies. Macmillan International Higher Education.

Healey, P. (2007). Urban complexity and spatial strategies: Towards a relational planning for our times. Routledge, Abingdon.

Healey, P. (2009). City regions and place development. Regional Studies 43: 6, 831-843. doi:10.1080/00343400701861336

Herrmann, D. L., W. D. Shuster, A. L. Mayer, \& A. S. Garmestani (2016). Sustainability for shrinking cities. Sustainability (Switzerland) 8: 9. doi:10.3390/su8090911

Hirt, S., \& R. Beauregard, (2019). Must shrinking cities be distressed cities? A historical and conceptual critique. International Planning Studies. doi:10.1080/13563475.2019.1661226

Hollander, J. B. (2011). Can a city successfully shrink? Evidence from survey data on neighborhood quality. Urban Affairs Review 47: 1 , 129-141. doi:10.1177/1078087410379099

Hollander, J. B., \& J. Németh, (2011). The bounds of smart decline: A foundational theory for planning shrinking cities. Housing Policy Debate 21: 3,
349-367.

Hollander, J. B., \& F. J. Popper (2011). Sunburnt cities: The Great Recession, depopulation and urban planning in the American Sunbelt. Taylor and Francis, Oxfordshire.

Hospers, G.-J. (2014). Policy responses to urban shrinkage: From growth thinking to civic engagement. European Planning Studies 22: 7 , 1507-1523.

Hospers, G.-J., \& J. Syssner (2018). Dealing with Urban and Rural Shrinkage: Formal and Informal Strategies. LIT Verlag, Münster.

Huber, M. T. (2013). Lifeblood: Oil, Freedom, and the Forces of Capital. University of Minnesota Press, Minneapolis.

Hudeček, T., P. Hnilička, M. Dlouhý, L. Leňo Cutáková \& M. Leňo (2019). Urban structures, population density and municipal expenditures: An empirical study in the Czech Republic. Urban Studies 56: 16, 3450-3465. doi:10.1177/0042098018813268

Humer, A. (2018). Strategic spatial planning in shrinking regions. In G.-J. Hospers \& J. Syssner (eds.): Dealing with urban and rural shrinkage: Formal and informal strategies. LIT Verlag, Münster.

Jackson, T. (2016). Prosperity Without Growth : Foundations for the Economy of Tomorrow. Routledge, Abingdon.

Jacobs, J. (2016). The death and life of great American cities. Vintage, New York.

Jakle, J. A., \& D. Wilson (1992). Derelict Landscapes: The Wasting of America's Built Environment. Rowman \& Littlefield, Lanham.

Jessen, J. (2012). Conceptualizing shrinking cities - A challenge for planning theory. In Piro, R. \& R. Ganser (eds.): Parallel Patterns of Shrinking Cities and Urban Growth: Spatial Planning for Sustainable Development of City Regions and Rural Areas, 45-58. Ashgate Publishing, Farnham.

Jessop, B., N. Brenner, \& M. Jones (2008). Theorizing sociospatial relations. Environment and Planning D: Society and Space 26: 3, 389-401.

Jonsson, R., \& J. Syssner (2018). New demography, old infrastructure: The management of fixed assets in shrinking municipalities in Sweden. Dealing with urban and rural shrinkage: Formal and informal strategies 5, 31.

Karl, G., S. Walter \& S. Thomas (1993). Die Planungsstrategie der IBA Emscher Park. Eine Annäherung. RaumPlanung 61, 112-118.

Kinossian, N. (2018). Planning strategies and practices in non-core regions: a critical response. European Planning Studies 26: 2, 365-375. doi $: 10.1080 / 09654313.2017 .1361606$

Kirkpatrick, L. O. (2015). Urban Triage, City Sys- 
tems, and the Remnants of Community: Some "Sticky" Complications in the Greening of Detroit. Journal of Urban History 41: 2, 261-278. doi:10.1177/0096144214563503

Knoop, B. (2014). Nothing but Growth for Shrinking Cities? Urban Planning and its Influencing Factors in Poland. Paper presented at the Fourth International Conference on Degrowth for Ecological Sustainability and Social Equity, Leipzig.

Kreichauf, R. (2014). Being on the Losing Side of Global Urban Development? The Limits to Managing Urban Decline. Retrieved from https:// EconPapers.repec.org/RePEc:wiw:wiwrsa:ersa14p94

Kroll, F., \& N. Kabisch, (2012). The Relation of Diverging Urban Growth Processes and Demographic Change along an Urban-Rural Gradient. Population, Space and Place 18: 3, 260-276. doi:10.1002/psp.653

Kübler, A., C. Strauß \& B. Warner (2012). Regional land use management under shrinkage tendencies in the region Halle-Leipzig. In Piro, R. \& R. Ganser (eds.): Parallel Patterns of Shrinking Cities and Urban Growth: Spatial Planning for Sustainable Development of City Regions and Rural Areas, 93-109. Ashgate Publishing, Farnham.

Kunzmann, K. (2013). Strategic planning: A chance for spatial innovation and creativity. DISP 49: 3, 28-31. doi:10.1080/02513625.2013.859003

Lehtinen, A. (2018). Degrowth in city planning. Fennia - International Journal of Geography 196: 1. doi:10.11143/fennia.65443

Leick, B., \& T. Lang (2018). Re-thinking non-core regions: planning strategies and practices beyond growth. European Planning Studies 26: 2, 213-228. doi:10.1080/09654313.2017.1363398

Liebmann, H., \& T. Kuder (2012). Pathways and strategies of urban regeneration-deindustrialized cities in eastern Germany. European Planning Studies 20: 7, 1155-1172.

Logan, J. R., \& H. L. Molotch (2007). Urban fortunes: The political economy of place. University of California Press, Berkeley.

Mäding, H. (2004). Demographic change and local government finance: Trends and expectations. German Journal of Urban Studies 43: 1.

Magnaghi, A. (2005). The urban village: a charter for democracy and sustainable development in the city. Zed Books, London.

Mallach, A. (2017). What we talk about when we talk about shrinking cities: The ambiguity of discourse and policy response in the United States. Cities 69, 109-115. doi:10.1016/j.cities.2017.01.008

Martinez-Fernandez, C., T. Weyman, S. Fol, I. Audirac, E. Cunningham-Sabot, T. Wiechmann \& H. Yahagi (2016). Shrinking cities in Australia,
Japan, Europe and the USA: From a global process to local policy responses. Progress in Planning 105, 1-48.

Martinez-Fernandez, C., I. Audirac, S. Fol \& E. Cunningham-Sabot (2012). Shrinking cities: Urban challenges of globalization. International Journal of Urban and Regional Research 36: 2, 213-225.

Massey, D. (2005). For Space. SAGE Publications, Los Angeles.

Melis, K. G. (2013). Naar een leefbare regio: Regionale leefbaarheid en identiteiten in Noord-Groningen tijdens de tweede helft van de twintigste eeuw.

Mintzberg, H. (1990). Strategy formation: Schools of thought. Perspectives on Strategic Management 1968, 105-235.

Miot, Y. (2015). Residential Attractiveness as a Public Policy Goal for Declining Industrial Cities: Housing Renewal Strategies in Mulhouse, Roubaix and Saint-Etienne (France). European Planning Studies 23: 1, 104-125. doi:10.1080/0 9654313.2013.820098

Moss, T. (2008). 'Cold spots' of urban infrastructure: 'Shrinking' processes in Eastern Germany and the modern infrastructural ideal. International Journal of Urban and Regional Research 32: 2, 436-451. doi:10.1111/j.1468-2427.2008.00790.x

Moulaert, F., F. Martinelli, E. Swyngedouw \& S. Gonzalez (2005). Towards alternative model(s) of local innovation. Urban Studies 42: 11, 1969-1990.

Müller, B., \& S. Siedentop (2004). Growth and shrinkage in Germany - Trends, perspectives and challenges for spatial planning and development. German Journal of Urban Studies 44: 1, 14-32.

Murtagh, B. (2016). The role of the social economy in the Shrinking city. In Schlappa, H. \& W. J. V. Neill (eds.): Future Directions for the European Shrinking City, 55-68. Taylor and Francis, Oxfordshire.

Nuissl, H., \& D. Rink (2005). The 'production'of urban sprawl in eastern Germany as a phenomenon of post-socialist transformation. Cities 22: 2, 123-134.

Oswalt, P., K. Overmeyer \& P. Misselwitz (2013). Urban Catalyst: The Power of Temporary Use. DOM Publishers, Berlin.

Oswalt, P., \& T. Rieniets (2006). Atlas of shrinking cities. Hatje Cantz, Stuttgart.

Pallagst, K., R. Fleschurz \& S. Said (2017). What drives planning in a shrinking city? Tales from two German and two American cases. Town Planning Review 88: 1, 15-28.

Pallagst, K., R. Fleschurz, \& F. Trapp (2017). Greening the shrinking city - policies and planning approaches in the USA with the example of Flint, Michigan. Landscape Research 42: 7, 716-727. Pallagst, K., \& T. Wiechmann (2004). Shrinking 
smart? Städtische Schrumpfungsprozesse in den USA. In Gestring N., H. Glasauer, W. Hannemann \& W. Petrowsky (eds.): Jahrbuch StadtRegion 2004/05, Schwerpunkt "Schrumpfende Städte", 105-127. VS Verlag, Wiesbaden.

Panagopoulos, T., M. H. Guimarães \& A. P. Barreira (2015). Influences on citizens' policy preferences for shrinking cities: A case study of four Portuguese cities. Regional Studies, Regional Science 2: 1, 141-170. doi:10.1080/21681376 .2015 .1010225

Popper, D. E., \& F. J. Popper (2002). Small can be beautiful: Coming to terms with decline. Planning 68, 20-23.

Provincie Noord-Holland (2017a). Provinciale Ruimtelijke Verordening.

Provincie Noord-Holland (2017b). Uitvoeringsregeling regionale afspraken nieuwe stedelijke ontwikkelingen.

Quinn, J. B., \& J. Voyer (1998). Logical incrementalism: Managing strategy formation. The Strategy Process Prentice Hall Europe, 103-110.

Radzimski, A. (2018). Involving small landlords as a regeneration strategy under shrinkage: evidence from two East German cases. European Planning Studies 26: 3, 526-545. doi:10.1080/09654313 .2017.1391178

Reverda, N., M. Hermans \& N. Maurer (2018). Towards a culture of degrowth. In Hospers, G.J. \& J. Syssner (eds.): Dealing with urban and rural shrinkage: Formal and informal strategies, 17-30). LIT Verlag, Münster.

Rink, D., A. Haase, K. Grossmann, C. Couch \& M.Cocks (2012). From long-term shrinkage to re-growth? The urban development trajectories of Liverpool and Leipzig. Built Environment 38: 2, 162-178. doi:10.2148/benv.38.2.162

Ročak, M., G.-J. Hospers \& N. Reverda (2016a). Civic action and urban shrinkage: Exploring the link. Journal of Urban Regeneration and Renewal 9: 4, 406-418.

Ročak, M., G. J. Hospers, \& N. Reverda (2016b). Searching for social sustainability: The case of the shrinking city of Heerlen, the Netherlands. Sustainability (Switzerland) 8: 4. doi:10.3390/ su8040382

Rodríguez-Pose, A. (2018). The revenge of the places that don't matter (and what to do about it). Cambridge Journal of Regions, Economy and Society 11: 1, 189-209. doi:10.1093/cjres/rsx024

Rousseau, M. (2009). Re-imaging the City Centre for the Middle Classes: Regeneration, Gentrification and Symbolic Policies in 'Loser Cities'. International Journal of Urban and Regional Research 33: 3, 770-788. doi:10.1111/j.14682427.2009.00889.x
Rutgers-Zoet, J., \& G.-J. Hospers (2018). Regional collaboration in rural areas: The case of the Achterhoek. In Hospers, G.-J. \& J. Syssner (eds.): Dealing with urban and rural shrinkage: Formal and informal strategies, 87-99. LIT Verlag, Münster.

Rydin, Y. (2013). The future of planning: Beyond growth dependence. Policy Press, Bristol.

Schatz, L. (2017). Going for growth and managing decline: the complex mix of planning strategies in Broken Hill, NSW, Australia. Town Planning Review 88: 1, 43-57.

Schilling, J., \& J. Logan (2008). Greening the rust belt: A green infrastructure model for right sizing America's shrinking cities. Journal of the American Planning Association 74: 4, 451-466. doi:10.1080/01944360802354956

Schmidt, S., S. Fina \& S. Siedentop (2015). Post-socialist Sprawl: A Cross-Country Comparison. European Planning Studies 23: 7, 1357-1380. doi:10.1080/09654313.2014.933178

Schulz, C. (2018). Postwachstum in den Raumwissenschaften. Akademie fuer Raumforschung und Landesplanung. Nachrichten 47: 4, 11-14.

Siebel, W., \& H. Häußermann (1987). Neue Urbanität. Suhrkamp, Frankfurt.

Siedentop, S., \& S. Fina (2010). Urban sprawl beyond Growth: The effect of demographic change on infrastructure costs. Flux 79-80, 90-100.

Slach, O., V. Bosák, L. Krtička, A. Nováček \& P. Rumpel (2019). Urban shrinkage and sustainability: Assessing the nexus between population density, urban structures and urban sustainability. Sustainability (Switzerland) 11: 15. doi:10.3390/ su11154142

Slupina, M., S. Dähner, L. Reibstein \& R. Klingholz (2019). Die demografische Lage der Nation: Wie zukunftsfähig Deutschlands Regionen sind. Berlin-Institut, Berlin.

Sorkin, D. L. (1984). Strategies for cities and counties: A strategic planning guide. Public Technology.

Sousa, S., \& P. Pinho (2015). Planning for Shrinkage: Paradox or Paradigm. European Planning Studies 23: 1, 12-32. doi:10.1080/09654313.2 013.820082

Steinführer, A., \& A. Haase (2007). Demographic change as a future challege for cities in East Central Europe. Geografiska Annaler, Series B: Human Geography 89: 2, 183-195. doi:10.1111/ j.1468-0467.2007.00247.x

Steinführer, A., P. Küpper \& A. Tautz (2014). Adapt and cope: Strategies for safeguarding the quality of life in a shrinking ageing region. Comparative population studies 39: 2 .

Strauß, C. (2012). The importance of strategic spatial 
goals for the planning process under shrinkage tendencies. In Piro, R. \& R. Ganser (eds.): Parallel Patterns of Shrinking Cities and Urban Growth: Spatial Planning for Sustainable Development of City Regions and Rural Areas, 83-92. Ashgate Publishing, Farnham.

Strohmeier, K. P. \& S. Bader (2004). Demographic decline, segregation and social urban renewal in old industrial metropolitan areas. Deutsche Zeitschrift für Kommunalwissenschaften 44: 1, 51-69.

Stryjakiewicz, T., R. Kudłak, P. Ciesiółka, B. Kołsut \& P. Motek (2018). Urban regeneration in Poland's non-core regions. European Planning Studies 26: 2, 316-341. doi:10.1080/09654313.2017. 1361603

Troutman, P. (2004). A growth machine's plan B: Legitimating development when the value-free growth ideology is under fire. Journal of Urban Affairs 26: 5, 611-622.

Turok, I., \& V. Mykhnenko (2007). The trajectories of European cities, 1960-2005. Cities 24: 3, 165-182.

van Assche, K., M. Gruezmacher, \& L. Deacon (2020). Land use tools for tempering boom and bust: Strategy and capacity building in governance. Land Use Policy 93, 103994. doi:10.1016/j. landusepol.2019.05.013

van den Berg, L., R. Drewett, L. H. Klaassen, A. Rossi, \& C. H. T. Vijverberg (1982). Urban Europe: A Study of Growth and Decline. Pergamon Press, Oxford.

van Duinen, L. (2013). Mainport and corridor: Exploring the mobilizing capacities of Dutch spatial concepts. Planning Theory \& Practice 14: 2, 211-232.

Walther, J. (2016). Managing service infrastructures in Shrinking cities: Challenges and opportunities. In Schlappa, H. \& W. J. V. Neill (eds.): Future Directions for the European Shrinking City, 155-168. Taylor and Francis, Oxfordshire.

Wiechmann, T. (2008a). Errors expected-aligning urban strategy with demographic uncertainty in shrinking cities. International Planning Studies 13: 4, 431-446.

Wiechmann, T. (2008b). Planung und Adaption: Strategieentwicklung in Regionen, Organisationen und Netzwerken. Rohn, Dortmund.

Wiechmann, T., \& M. Bontje (2015). Responding to tough times: Policy and planning strategies in shrinking cities. European Planning Studies 23: 1-11.

Wolff, M. (2018). Understanding the role of centralization processes for cities - Evidence from a spatial perspective of urban Europe 1990-2010. Cities 75, 20-29.
Wolff, M., \& T. Wiechmann (2018). Urban growth and decline: Europe's shrinking cities in a comparative perspective 1990-2010. European Urban and Regional Studies 25: 2, 122-139.

Zakirova, B. (2010). Shrinkage at the urban fringe: Crisis or opportunity? Berkeley Planning Journal 23: $1,58-82$. 